\title{
EFEKTIVITAS PEMBELAJARAN TEMATIK PADA MATERI PENDIDIKAN AGAMA ISLAM (PAI) DI MI HIDAYATUL ISLAM MENTORO TUBAN
}

\author{
I'anatut Thoifah ${ }^{1}$
}

\begin{abstract}
Learning is a process two-way communication, teaching performed by the teacher, as an educator the students learned performed by a student. It is a model that a many forms, between one to the other to have different characteristics. That can be appropriated with characteritics every student all that is already deeply affect the quality of learning process and the result of the students. This research is to find out how the thematic and what steps the thematic on a learn in elementary school of MI Hidayatul Islam Mentoro. And this research is able to identify the effectiveness of thematic To get the data needed, researchers use some method is the observation, the interview, documentation. While for the accumulated data processing using descriptive analysis by researchers. Research shows that models basically thematic's learning Islamic Education (PAI) in elementary school of MI Hidayatul Islam Mentoro Tuban.
\end{abstract}

Key world: Efektivity, Learning, Thematic

\section{A. Pendahuluan}

Salah satu tugas sekolah adalah memberikan pengajaran kepada anak didik. Mereka harus memperoleh kecakapan dan pengetahuan dari sekolah, disamping mengembangkan pribadinya. Pemberian kecakapan dan pengetahuan kepada siswa disebut dengan proses belajar mengajar. Proses belajar mengajar diberikan oleh guru di sekolah dengan pendekatan-pendekatan, cara-cara, atau metodemetode tertentu.

Dalam proses belajar mengajar, guru tetap menduduki posisi yang penting sebab mulai dari perencanaan pembelajaran sampai pada pelaksanaan pembelajaran bahkan sampai pada proses evaluasi guru yang mendesainya. Meskipun demikian, keberhasilan pembelajaran

1 Dosen Tetap UNISLA Lamongan. Alamat Jalan veteran No.53A Lamongan Telp. 0322-324706. 
tidak mutlak terfokus pada guru, karena masih ada komponen lain dalam proses belajar mengajar.

Sebagaimana yang disampaikan E. Mulyasa (2007:35) bahwa semua orang yakin bahwa guru memiliki andil yang sangat besar terhadap keberhasilan pembelajaran di sekolah. Guru sangat berperan dalam membantu perkembangan peserta didik untuk mewujudkan tujuan hidupnya secara optimal. Keyakinan ini muncul karena manusia adalah makhluk lemah, yang dalam perkembanganya senantiasa membutuhkan orang lain, sejak lahir bahkan pada saat meninggal. Semua itu menunjukan bahwa setiap orang membutuhkan orang lain dalam perkembanganya. Demikian halnya peserta didik, ketika orang tua mendaftarkan anaknya ke sekolah pada saat itu juga ia menaruh harapan terhadap guru, agar anaknya dapat berkembang secara optimal. Minat, bakat, kemampuan, dan potensi-potensi lain yang dimiliki oleh peserta didik tidak akan berkembang secara optimal tanpa bantuan guru. Dalam hal ini guru perlu memperhatikan peserta didik secara individual, karena antara satu peserta didik dengan yang lain memiliki perbedaan yang sangat mendasar.

Dalam kegiatan belajar mengajar yang berlangsung telah terjadi interakasi yang bertujuan. Guru dan anak didiklah yang menggerakkanya. Interaksi yang bertujuan itu disebabkan gurulah yang memaknainya dengan menciptakan lingkungan yang bernilai edukatif demi kepentingan anak didik dalam belajar. Guru ingin memberikan layanan yang terbaik bagi anak didik, dengan menyediakan lingkungan yang menyenangkan dan menggairahkan. Guru berusaha menjadi pembimbing yang baik dengan peranan yang arif dan bijaksana, sehingga tercipta hubungan dua arah yang harmonis antara dua yakni penggerak kegiatan belajar mengajar, guru dengan anak didik.

Ketika kegiatan belajar mengajar itu berproses, guru harus dengan ikhlas dalam bersikap dan berbuat, serta mau memahami anak didiknya dengan segala konsekuensinya. Semua kendala yang terjadi dan dapat menjadi penghambat jalannya proses belajar mengajar, baik yang berpangkal dari perilaku anak didik maupun yang bersumber dari luar diri anak didik, harus guru hilangkan, dan bukan membiarkanya. Karena keberhasilan belajar mengajar lebih banyak ditentukan oleh guru dalam mengelola kelas. 
Sebelum proses belajar mengajar berlangsung terlebih dulu guru juga membuat program, mulai dari program tahunan, program semester, rencana pekan efektif, silabus, rencana pembelajaran sampai pada penggunaan pendekatan yang akan diterapkanya, sebab dengan pendekatan guru akan tahu keberadaan anak didik, mungkin dari bakat atau minat secara dini akan diketahui oleh guru. Hal tersebut dilakukan oleh seorang guru agar proses pembelajaran itu dapat mencapai target.

Sebagaimana yang dikatakan oleh Syaiful Bahri Djamarah dan Aswan Zain bahwa dalam mengajar, guru harus pandai menggunakan pendekatan secara arif dan bijaksana, bukan sembarangan yang bisa merugikan anak didik. Pandangan guru terhadap anak didik akan menentukan sikap dan perbuatan. Setiap guru tidak selalu mempunyai pandangan yang sama dalam menilai anak didik. Hal ini akan mempengaruhi pendekatan yang guru ambil dalam pengajaran. Guru yang memandang anak didik sebagai pribadi yang berbeda dengan anak didik lainnya akan berbeda dengan guru yang memandang anak didik sebagai makhluk yang sama dan tidak ada perbedaan dalam segala hal. Maka adalah penting meluruskan pandangan yang keliru dalam menilai anak didik. Sebaiknya guru memandang anak didik sebagai individu dengan segala perbedaan, sehingga mudah melakukan pendekatan dalam pengajaran. (Syaifil Bahri Djamarah dan Aswan Zain, 2006: 54)

Adapun pendekatan yang dipilih, yang terpenting dalam pembelajaran adalah menempatkan peserta anak didik sebagai pusat aktivitas. Peserta didik tidak hanya terbatas "mempelajari tentang suatu hal", melainkan bagaimana proses belajar mengajar itu mampu memperkaya khazanah pengalaman belajar dan mempelajari bagaimana cara belajar. Proses pengalaman belajar tersebutdituangkan dalam kegiatan belajar mengajar dan mengembangkan fenomena alam sekitarnya. Dalam pembelajaran tematik, pembelajaran tidak semata-mata mendorong peserta didik untuk mengetahui (learning to know), tapi belajar juga untuk melakukan (learning to do), belajar untuk menjadi (learning to be), dan belajar untuk hidup bersama (learning to live together).

Olehkarenaitu,kurikulumnasionalmembutuhkanpengembangan dan penyesuaian dengan kebutuhan serta kultur madrasah dan 
masyarakat. Pembelajaran tematik dalam hal ini, menjadi salah satu alternatif menyiasati kurikulum yang padat dan muatan kegiatan yang banyak dengan berbagai mata pelajaran. Pendekatan tematik tidak mengesampingkan kurikulum nasional, justru merupakan upaya strategis untuk mengembangkan dan melaksanakanya secara efisien dan efektif. Oleh karena itu, pendekatan pembelajaran tematik mengandalkan infrastruktur dan tenaga pendidik, serta fasilitas yang memadai. Pembelajaran tematik dimaksudkan sebagai kegiatan pembelajaran dengan memadukan materi beberapa mata pelajaran dalam satu tema.(Departeman Agama, 2005: 4)

Guru dituntut untuk mampu menyampaikan dan membuat pembelajaran yang efektif. Efektivitas di sini bermakna ketepatan guna, hasil guna, menunjang tujuan. (Iyus Apartanto dan M. Dahlan Al Bahri, 1994: 128) Sedangkan menurut W.J.S. Purwodarminto (1987: 219) berpendapat bahwa Efektifitas adalah: keberhasilan guna atau keberhasilan dan kegunaan dari suatu pekerjaan yang lebih tepat dan mantap. Sejalan dengan hal tersebut, Syaiful juga menjelaskan bahwa pembelajaran ialah proses komunikasi dua arah, mengajar dilakukan oleh pihak guru sebagai pendidik, sedangkan belajar dilakukan oleh peserta didik sebagai murid. (Syaiful Sagala, 2006: 61)

Menurut Najib Sulhan (2006: 7), pembelajaran adalah suatu sistem atau proses membelajarkan subjek didik/pembelajar yang direncanakan atau didesain, dilaksanakan dan dievaluasi secara sistematis agar subjek didik/pembelajar dapat mencapai tujuantujuan pembelajaran secara efektif dan efisien.

Sejalan dengan hal tersebut, pembelajaran adalah suatu proses yang dinamis, berkembang secara terus menerus sesuai dengan pengalaman siswa. Semakin banyak pengalaman yang dilakukan siswa, maka akan semakin kaya, luas, dan sempurna pengetahuan mereka. (Wina Sanjaya, 2005: 194)

Dari beberapa pengertian di atas peneliti menyimpulkan bahwa efektivitas pembelajaran tematik adalah keberhasilan proses belajar mengajar dengan mengintegrasikan materi dari beberapa mata pelajaran dalam satu topik pembicaraan yang disebut dengan tema. 
Dalam kegiatan belajar mengajar yang melahirkan interaksi unsur-unsur manusiawi adalah sebagai suatu proses dalam rangka mencapai tujuan pengajaran. Guru dengan sadar berusaha mengatur lingkungan belajar agar siswa semakin bergairah dan bersemangat. Dengan seperangkat teori dan pengalaman yang dimiliki, guru menggunakannya untuk mempersiapkan program pengajaran dengan baik dan sistematis.

Sedang dalam menyampaikan materi banyak model pembelajaran yang diterapkan oleh guru, karena model pembelajaran saat ini banyak bentuknya, yang antara yang satu dengan yang lain mempunyai karakteristik yang berbeda-beda. Hal itu dapat disesuaikan dengan karakteritik setiap siswa. Semua yang sudah didesain sangat mempengaruhi kualitas proses dan hasil belajar siswa. Dari sekian banyak model pembelajaran itu diantaranya adalah model pembelajaran tematik. Sedang makna dari pembelajaran tematik tersebut akan peneliti uraikan berikut ini.

Dalam buku dari Departemen Agama Direktorat Jenderal Kelembagaan Agama Islam, Pedoman Pelaksanan Pembelajaran Tematik mengatakan bahwa pembelajaran tematik adalah pembelajaran tematik merupakan pola pembelajaran yang mengintegrasikan pengetahuan, keterampilan, kreativitas, nilai dan sikap pembelajaran dengan menggunakan tema. Pembelajaran tematik dengan demikian adalah "pembelajaran terpadu atau terintegrasi" yang melibatkan beberapa pelajaran bahkan lintas rumpun mata pelajaran yang diikat dalam tema-tema tertentu. Pembelajaran ini melibatkan beberapa kompetensi dasar, hasil belajar, dan indikator dari suatu mata pelajaran atau bahkan beberapa mata pelajaran.

Keterpaduan dalam pembelajaran ini dapat dilihat dari aspek proses atau waktu, aspek kurikulum, dan aspek belajar mengajar. Diterapkanya pendekatan tematik dalam pembelajaran, membuka ruang yang luas bagi peserta didik untuk mengalami sebuah pengalaman belajar yang lebih bermakna, berkesan, dan menyenangkan.

Pengertian yang sama yang disampaikan Najib Sulhan dalam bukunya Pembangunan Karakter Anak Manajemen Pembelajaran Guru Menuju Sekolah Efektif bahwa model pembelajaran tematik ini memungkinkan terintegrasinya antar konsep, antar pokok bahasan 
dalam satu mata pelajaran atau bahkan antar pokok bahasan/tema pada mata pelajaran yang lain. Dalam hal ini, guru harus mampu membangun bagan keterpaduan melalui tema.

Model pembelajaran tematik juga sering disebut dengan model pembelajaran terpadu. Pembelajaran terpadu sebagai suatu konsep yang merupakan pendekatan proses belajar mengajar yang melibatkan beberapa mata pelajaran untuk memberikan pengalaman yang bermakna kepada anak. Dikatakan bermakna karena dalam pembelajaran terpadu ini anak-anak diajak untuk memahami konsep-konsep yang mereka pelajari melalui pengalaman langsung dan menghubungkannya dengan konsep lain yang sudah mereka pelajari.

Hakikat pembelajaran terpadu merupakan suatu sistem pembelajaran yang memungkinkan siswa (secara individu maupun kelompok) aktif mencari, menggali, dan menemukan konsep serta prinsip keilmuan secara holistik, bermakna, dan autentik. Dalam pengembangan pembelajaran tematik atau terpadu di sekolah dasar ada beberapa hal yang mendasari, yaitu:

1. Sesuai dengan penghayatan dunia kehidupan anak yang bersifat holistik

2. Sesuai dengan pemetaan mata pelajaran-mata pelajaran di sekolah dasar sehingga mampu membuahkan penguasaan isi pembelajaran secara utuh.

3. Idealisasi pelaksanaan kurikulum 1994 yang selayaknya dikembangkan secara integratif.

Pelaksanaan model pembelajaran tematik ini mempunyai tiga sasaran utama, yaitu: keterpaduan materi pengajaran, keterpaduan prosedur penyampaian, dan keterpaduan pengalaman belajar. Keterpaduan materi pelajaran merupakan suatu pendekatan atau bentuk organisasi materi pelajaran sebagai suatu stimulus yang akan dipelajari siswa. Keterpaduan materi ini dapat dilakukan dengan mengelompokkan materi yang mempunyai kedekatan.

Keterpaduan prosedur penyampaian mempunyai pengertian bahwa langkah dalam proses belajar mengajar bukan sekedar menyampaikan informasi. Siswa harus banyak terlibat dalam setiap 
kegiatan pembelajaran. Pembelajaran lebih diarahkan pada proses pemberian bantuan agar siswa mampu belajar untuk mengolah informasi secara maksimal.

Keterpaduan pengalaman belajar merupakan konsekuensi logis dari keterpaduan materi dan keterpaduan penyajian yang dilakukan guru. Hasil belajar siswa harus terbentuk dalam suatu akumulasi total. Hasil belajar bukan hanya ditandai oleh pengetahuan, ketrampilan, dan sikap secara sempit, melainkan harus menyangkut fungsi dan kemakmuran dari pengalaman belajar. Artinya siswa harus dapat memanfaatkan pengalaman tersebut dalam kehidupan sehari-hari.

Perubahan dari kurikulum 1994 menjadi kurikulum baru yang menekankan kompetensi dilakukan untuk mencapai hasil belajar yang lebih baik. Untuk mencapai harapan tersebut perlu dikembangkan strategibelajaryangtepat. Darisekianbanyakstrategibelajardankonsep pembelajaran harus dipilih yang paling efektif dan kontekstual. Salah satu strategi pembelajaran tersebut adalah pembelajaran kontekstual yang sekarang sedang dikembangkan, seperti pembelajaran efektif, CTL (Contevtual teaching Learning), AJEL (Active, Joyful, and Effective Learning), dan sebagainya. Prinsipnya, sebagai sebuah pembelajaran yang memiliki karakteristik pemberdayaan peserta didik, aktivitas, pemodelan, demontrasi, bernyanyi, menghasilkan karya, dan terintegrasi dengan kehidupan nyata peserta didik (kontekstual), maka dalam prakteknya pembelajaran tematik sekuat mungkin meminimalkan penerapan metode ceramah. Adapun karakteristik pembelajaran tematik adalah sebagai berikut:

1. Terintegrasi dengan lingkungan atau bersifat kontekstual, artinya pembelajaran dikemas dalam sebuah format keterkaitan antara "kemampuan peserta didik dalam menemukan masalah" dengan "memecahkan masalah nyata yang dihadapi dalam kehidupan sehari-hari".

2. Memiliki tema sebagai alat pemersatu beberapa mata pelajaran atau bahan kajian.

3. Menggunakan prinsip belajar sambil bermain dan menyenangkan (joyful learning).

4. Pembelajaran memberikan pengalaman langsung yang bermakna bagi peserta didik. 
5. Menanamkan konsep dari berbagai mata pelajaran atau bahan kajian dalam satu proses pembelajaran tertentu.

6. Pemisahan atau pembedaan antara satu mata pelajaran dengan mata pelajaran yang lain sulit dilakukan.

7. Pembelajaran dapat berkembang sesuai dengan kemampuan, kebutuhan, dan minat peserta didik.

8. Pembelajaran bersifat fleksibel.

9. Penggunaan variasi metode dalam pembelajaran.

Dalam pemaparan sebelumnya sudah dijelaskan bahwa pembelajaran tematik diarahkan agar proses pembelajaran menjadi lebih bermakna bagi peserta didik. Dengan menerapkan pembelajaran tematik, peserta didik dan guru banyak mendapatkan manfaat, di antara manfaat tersebut adalah (Departeman Agama, Direktorat Jendral Kelembagaan Agama Islam, Pedoman, 17):

1. Pembelajaran mampu meningkatkan pemahaman konseptual peserta didik terhadap realitas sesuai dengan tingkat perkembangan intelektualnya, disadari atau tidak, setiap anak selalu memanipulasi objek dan berinteraksi dengan orang lain. Pada saat itu, mereka memperoleh informasi yang relevan, kemudian memadukan dengan pengetahuan dan pemahaman yang telah mereka miliki sebelumnya. Dari proses tersebut, anak-anak mengembangkan sejumlah pengalaman, membangun pengetahuan, dan pada akhirnya mengembangkan konsep baru tentang suatu realitas.

2. Pembelajaran tematik memungkinkan peserta didik mampu mengeksplorasi pengetahuan melalui serangkaian proses kegiatan pembelajaran. Melalui pembelajaran tema, proses mental anak bekerja secara aktif dalam menghubungkan informasi yang terpisah-pisah menjadi satu kesatuan yang utuh. Pembelajaran tema memudahkan peserta didik untuk menghubungkan halhal lain yang mereka pelajari dalam kegiatan lain, juga dalam pembelajaran ini peserta didik diarahkan untuk mengintegrasikan isi dan proses pembelajaran lintas kompetensi sekaligus, misalnya antara pengembangan kognisi, estetika, dan bahasa. Penggalian pemahaman peserta didik dilakukan dengan cara mendorong terfungsikanya berbagai gaya belajar peserta didik, baik melalui 
pengalaman mendengar (audio), melihat (visual), interaksi interpersonal (hubungan sosial), maupun gaya belajar lainnya. Ketika pembelajaran dipandu oleh tema, tentu pengalamanpengalaman tersebut akan membuat peserta didik semakin tertarik untuk lebih mengetahui suatu persoalan (tema) secara lebih mendalam. Sehingga, secara psikologis proses pembelajaran seperti ini mampu menjawab kebutuhan dan keinginan peserta didik terhadap problem (tema-tema khusus) yang ada di benak mereka.

3. Pembelajaran tematik mampu meningkatkan keeratan hubungan antar peserta didik. Tema-tema pembelajaran yang erat hubunganya dengan pola kehidupan sosial, sangat membantu peserta didik agar mampu beradaptasi dan berganti peran dalam melakukan pekerjaan yang berbeda. Misalnya, tema "organisasi" memungkinkan peserta didik mempunyai peran yang berbeda satu sama lain. Dalam tema ini saja, antara peserta didik dengan peserta didik yang lain dapat berganti peran dan fungsi yang berbeda. Belum lagi ketika peserta didik bekerja sama dalam melakukan kegiatan lainya, tentu setiap peserta didik selalu belajar beradaptasi dan dihadapkan dengan peran-peran yang berbeda.

4. Pembelajaran tematik membantu guru dalam meningkatkan profesionalismenya. Pembelajaran tematik membutuhkan kecermatan dan keseriusan guru, mulai dari menemukan tema yang kontekstual, merancang rencana pembelajaran, menyiapkan metode pembelajaran yang tepat, merumuskan tujuan pembelajaran, melaksanakan pembelajaran secara konsisten dengan tema pembelajaran, sampai menyusun instrumen penilaian (evaluasi) yang relevan dengan kegiatan pembelajaran. Serangkaian kegiatan ini tentu membutuhkan bukan hanya ketekunan dan kesungguhan dalam merancang desain pembelajaran, melainkan juga secara tidak langsung membuat guru tertantang untuk mempelajari hal-hal baru yang dibutuhkan dalam menjalankan tugas dan fungsinya sebagai seorang pendidik. Sehingga, dengan proses tersebut guru selalu memperbaharui wawasan dan kompetensinya. 
Menurut Najib Sulhan (2006:58) ada beberapa langkah untuk menyusun program model pembelajaran tematik, antara lain:

1. Membuat pemetaan kompetensi dasar pada tema-tema

2. Menentukan tema sentral

3. Memetakan pokok bahasan berdasarkan GBPP dan kurikulum yang berlaku

4. Mengalokasikan waktu dalam pembelajaran

5. Membuat bagan/skema keterpaduan melalui tema sentral

6. Merumuskan tujuan pembelajaran

7. Membuat skenario pembelajaran

8. Menentukan alat dan media pembelajaran

9. Merencanakan evaluasi

Dalam suatu urusan, keberhasilan merupakan tujuan mutlak yang ingin dicapai, baik itu tujuan jangka pendek, menegah, maupun jangka panjang. Untuk mencapai keberhasilan tersebut biasanya seseorang melakukan usaha-usaha, cara-cara tertentu dengan semangat yang tinggi agar apa yang diharapkan dapat terwujud dan sesuai dengan yang diharapkan.

Begitu pula guru, sebelum guru memulai proses belajar mengajar terlebih dulu membuat perangkat pengajaran. Perangkat pengajaran tersebut dibuat sedemikian rupa, mulai dari program tahunan, program semester, silabus sampai pada rencana pembelajaran. Hal itu semua dilakukan dan disiapkan guna untuk mencari out put pada anak didik atau keberhasilan yang ingin dicapainya.

\section{B. Metodologi Penelitian}

Penelitian ini bertujuan untuk mengetahui efektivitas pembelajaran tematik pada materi PAI di MI Hidayatul Islam Mentoro Tuban. Metode yang dipakai untuk mengumpulkan data dalam penelitian ini adalah field research, yaitu untuk penelitian yang dilakukan di kancah atau di medan terjadinya gejala-gejala. (Sutrisno Hadi, 2001: Jilid 1,10)

Populasi yang digunakan dalam penelitian ini adalah semua anak yang berada di kelas III pada MI Hidayatul Islam Mentoro Tuban yang berjumlah 21 siswa. Adapun variabel dalam penelitian ini diklasifikasikan menjadi dua, yaitu: 
a) Efektivitas Pembelajaran tematik sebagai variabel $X$ dengan indikator sebagai berikut:

- Kelayakan dan kualifikasi guru terhadap keberhasilan pembelajaran tematik

- Sistem dan media yang dapat menunjang pembelajaran tersebut

b) Hasil belajar siswa sebagai variabel $Y$ dengan indikator sebagai berikut:

- Nilai hasil belajar anak dalam raport

- Prestasi siswa.

Dalam hal ini metode pengumpulan data digunakan untuk memperoleh data yang diperlukan, baik yang berhubungan dengan studi literatur maupun yang dihasilkan dari data empiris melalui observasi, wawancara, dan dokumentasi. Sedangkan angket dan kuesioner digunakan untuk mendapatkan data-data dari obyek penelitian yang berupa data-data tentang model-model pembelajaran yang dipakai oleh guru, termasuk juga data-data tentang kegiatan belajar anak-anak.

Penskoran dilakukan untuk memasukan data-data angket yang telah diperoleh kemudian dijumlahkan masing-masing jawaban yang telah diberikan responden dalam angket penelitian yang terdiri atas 10 item soal dengan alternatif jawaban dan bobot nilai sebagai berikut:

1) Untuk alternatif jawaban a dengan skor 4

2) Untuk alternatif jawaban b dengan skor 3

3) Untuk alternatif jawaban c dengan skor 2

4) Untuk alternatif jawaban d dengan skor 1

Menentukan kualifikasi dan interval nilai dengan menggunakan rumus:

$\mathrm{R}=\mathrm{H}-\mathrm{L}+1^{12}$

Keterangan:

$\mathrm{R}=$ Jarak pengukuran range

$\mathrm{H}$ = Nilai tertinggi

$\mathrm{L}=$ Nilai terendah 
1 = Bilangan konstan

Jumlah interval

Adapun untuk menginterpretasikan nilai data yang telah diperoleh adalah sebagai berikut:

\begin{tabular}{|l|l|}
\hline \multicolumn{1}{|c|}{ Interval (i) } & \multicolumn{1}{c|}{ Interpretasi } \\
\hline Antara 81 sampai dengan 100 & Baik sekali \\
\hline Antara 61 sampai dengan 80 & Baik \\
\hline Antara 41 sampai dengan 60 & Cukup \\
\hline Antara 21 sampai dengan 40 & Kurang \\
\hline
\end{tabular}

- Menentukan table frekuensi dan mencari nilai rata-rata (mean dari variabel $(\mathrm{x})$ dan variabrl (y)

Untuk variabel $(x) M x=\sum x$

$\mathrm{N}$

Untuk variabel (y) $\mathrm{My}=\sum \mathrm{y}$

$\mathrm{N}$

b. Analisis uji hipotesis

Analisis uji hipotesis digunakan untuk mengolah data yang telah terkumpul dari hasil penelitian yang bersifat kuantitatif, maka pada tahapan ini peneliti menempuh langkah untuk mencari teknik antar prediktor dan krioteroium melalui teknik korelasi produk momen dengan rumus:

rry $=\Sigma x y$

$$
\left(\Sigma \mathrm{x}^{2}\right)\left(\Sigma \mathrm{y}^{2}\right)
$$

di mana:

$$
\Sigma x y=\Sigma x y-(\Sigma x X \Sigma y)
$$

$\mathrm{N}$

$$
\begin{array}{r}
\Sigma \mathrm{x}^{2}=\Sigma \mathrm{x}^{2}-\underline{\underline{\Sigma} \mathrm{x}^{\underline{2}}} \\
\mathrm{~N} \\
\Sigma \mathrm{y}^{2}=\Sigma \mathrm{y}^{2}-\underline{\Sigma \mathrm{y}^{\underline{2}}} \\
\mathrm{~N}
\end{array}
$$




\section{Hasil Penelitian}

Dalam pembelajaran tematik dapat dikatakan efektif adalah ketika nilai yang diperoleh siswa sesudah menggunakan tematik lebih meningkat bila dibanding sebelum menggunakan tematik. Hasil dan analisa data ini dibuat berdasarkan data yang diperoleh dari kegiatan pembelajaran tematik yang dilaksanakan di MI Hidayatul Islam Mentoro Kec. Soko Kab. Tuban pada mata pelajaran fiqih. Pada pelaksanaan ini peneliti menggunakan kelas III yang terdiri dari 21 siswa. Dalam analisis statistik thitung lebih besar dari pada $t$ tabel (3, $844>2,021)$. Dengan demikian, Ho ditolak dan Ha diterima.Pengujian hipotesis menyimpulkan bahwa perhitungan nilai antara variabel (x) yaitu pembelajaran sebelum menggunakan metode tematik dengan variabel (y) sesudah menggunakan pembelajaran tematik diperoleh nilai yang signifikan.

Dengan demikian dapat disimpulkan bahwa efektivitas pembelajaran tematik dapat meningkatkan hasil belajar siswa atau Ha diterima itu berarti terdapat perbedaan prestasi siswa antara sebelum menggunakan pembelajaran tematik dan sesudah menggunakan pembelajaran tematik.

Sedangkan hasil analisis non-statistik menunjukkan bahwa dari observasi dapat disimpulkan bahwa kelas anggota populasi mempunyai karakteristik yang sama sehingga memungkinkan untuk diadakan teknik sampling secara random. Sedangkan dari data observasi dapat disimpulkan sebagai berikut:

(1) Siswa semakin aktif dalam pembelajaran

(2) Interaksi antar siswa lebih hidup

(3) Dalam pembelajaran siswa menjadi lebih semangat

(4) Siswa lebih peka terhadap lingkungan, baik fenomena alam maupun realitas sosial yang terjadi di sekitar.

Pernyataan tersebut diperkuat oleh data angket yang diperoleh dianalisis berdasarkan prosentase hasil jawaban angket siswa berjumlah 21 anak. Hasil jawabannya adalah sebagai berikut:

(1) 47,6\% dari siswa merasa terkesan dan senang terhadap perpaduan dari beberapa mata pelajaran dalam satu tema, $23.8 \%$ kadangkadang, 14,3 \% tidak terkesan, dan 14,3 \% tetap tidak terkesan dengan perpaduan beberapa mata pelajaran dalam satu tema. 
I'anatut Thoifah - Efektivitas Pembelajaran Tematik Pada...

(2) 33,4 \% siswa merasa mudah mengaitkan hubungan suatu materi pelajaran yang satu dengan pelajaran yang lain, 47,6 \% siswa kadang-kadang mudah, dan $19 \%$ tidak merasakan

(3) 42,8 \% siswa selalu berkelompok dalam mengerjakan tugas, 38, $\%$ siswa sering berkelompok, 9,6 \% kadang-kadang, dan 9,6\% tidak pernah.

(4) $28,6 \%$ siswa merasa sangat cukup waktu yang diberikan guru untuk berfikir dan bertanya, 28,6 \% merasa cukup, 23,8 \% tidak cukup, dan $19 \%$ merasa kurang.

(5) 57,2 \% siswa selalu tidak senang dengan metode ceramah dan $42,8 \%$ siswa lagi mengatakan senang dengan metode ceramah.

(6) $47,6 \%$ siswa merasa tidak ada perbedaan antara satu mata pelajaran dengan pelajaran yang lain, 23,8\% siswa merasa kadangkadang, 23,8 \% merasa tidak ada perbedaan satu pelajaran dengan pelajaran yang lainya, dan hanya $4,8 \%$ siswa yang menyatakan tetap tidak ada perbedaan.

(7) $38 \%$ siswa merasa selalu terdorong giat belajar setelah berdiskusi, $19,1 \%$ siswa merasa sering terdorong giat belajar, 19,1 \% siswa kadang-kadang, dan 23,8 \% tetap tidak merasa terdorong setelah berdiskusi.

(8) 47,6 \% siswa sangat merasa sedang belajar sambil bermain, 23,8 $\%$ siswa sering merasa, $14,3 \%$ kadang-kadang, dan $14,3 \%$ tidak pernah merasa.

(9) $42,8 \%$ siswa menyatakan bahwa pembelajaran sangat sesuai dengan minat dan kebutuhan siswa, 9,6\% kadang-kadang sesuai, $33,4 \%$ siswa tidak sesuai, dan $14,2 \%$ sangat tidak sesuai dengan minat dan kebutuhan siswa.

(10) $71,4 \%$ siswa merasa sangat terdorong untuk bekerjasama, toleransi, dan komunikasi dengan teman, $19 \%$ siswa kadangkadang terdorong, dan 9,6 \% siswa tidak terdorong untuk kerjasama, toleransi maupun berkomunikasi.

Dari penjelasan tersebut $\mathrm{d}$ iatas, dapat diketahui bahwa efektivitas pembelajaran tematik pada mata pelajaran fiqih adalah dapat meningkatkan hasil belajar di MI Hidayatul Islam Mentoro Soko Tuban. Nilai-nilai tersebut menjadi bukti bahwa efektivitas pembelajaran tematik menjadi pendorong siswa dalam belajar. 
Fakta di lapangan menunjukkan bahwa pembelajaran model tematik berdampak pada keberhasilan belajar siswa.

\section{Pembahasan}

Setelah data terkumpul dan dianalisis, maka dapat diinterpretasikan sebagai berikut:

1. Berdasarkan hasil analisis statistik yang dilakukan, karena terhitung $\mathrm{t}$ hitung lebih besar dari pada $\mathrm{t}$ tabel $(3,844>2,021)$ maka Ho ditolak yang berarti $\mathrm{Ha}$ diterima atau terdapat perbedaan prestasi belajar siswa dalam pembelajaran sebelum menggunakan metode tematik dan sesudah menggunakan tematik. Hal ini berarti hipotesis penelitian ini diterima.

2. Berdasarkan hasil analisis data observasi, dapat diinterpretasikan bahwa dalam pembelajaran tematik keaktifan siswa lebih tampak dibandingkan dengan sebelum menggunakan metode tematik.

3. Berdasarkan hasil analisis angket, dapat diinterpretasikan bahwa pembelajaran tematik sesuai diterapkan di kelas III MI Hidayatul Islam Mentoro Soko Tuban, karena hampir 85\% siswa merasa:

a) Terkesan dan senang dengan perpaduan beberapa mata pelajaran dalam satu tema.

b) Mudah mengaitkan hubungan suatu materi pelajaran yang satu dengan pelajaran yang lain.

c) Selalu berkelompok dalam mengerjakan tugas.

d) Cukup waktu untuk berfikir dan bertanya.

e) Kurang tepat dengan hanya memakai metode ceramah.

f) Tidak ada perbedaan antara mata pelajaran yang satu dengan pelajaran yang lain.

g) Terdorong giat belajar setelah berdiskusi.

h) Bermain sambil belajar.

i) Telah sesuai dengan minat dan kebutuhan.

j) Terdorong untuk kerja sama, toleransi, dan komunikasi terhadap teman.

Dalam penelitian ini, peneliti menyadari bahwa penelitian ini masih jauh dari kata kesempurnaan, sebab masih banyak kekurangan 
dan kendala uang menjadi penghambat bagi terlaksananya penelitian ini. Hal ini terjadi karena keterbatasan kemampuan peneliti dan juga sarana pra-sarana yang kurang, baik dari waktu, sampel maupun indikator.

Pada saat peneliti mengadakan penelitian ini, yaitu penelitian tentang efektivitas pembelajaran tematik pada materi Pendidikan Agama Islam (PAI), yang dalam hal ini adalah Madrasah Ibtidaiyah Hidayatul Islam Mentoro Kecamatan Soko Tuban, hasilnya menunjukkan signifikan.

\section{E. Kesimpulan}

Pembelajaran tematik adalah pembelajaran terpadu sebagai suatu konsep yang merupakan pendekatan proses belajar mengajar yang melibatkan beberapa mata pelajaran untuk memberikan pengalaman yang bermakna kepada anak didik. Dikatakan bermakna karena dalam pembelajaran terpadu ini anak-anak diajak untuk memahami konsep-konsep yang mereka pelajari melalui pengalaman langsung dan menghubungkan dengan konsep lain yang sudah mereka pelajari. Sedangkan langkah-langkah pembelajaran tematik diantaranya:

a. Membuat pemetaan kompetensi dasar pada tema-tema

b. Menentukan tema sentral

c. Memetakan pokok bahasan berdasarkan GBPP dan kurikulum yang berlaku.

d. Mengalokasikan waktu dalam pembelajaran

e. Membuat bagan/skema keterpaduan melalui tema sentral

f. Merumuskan tujuan pembelajaran

g. Membuat skenario pembelajaran

h. Menentukan alat dan media pembelajaran

i. Merencanakan evaluasi 


\section{DAFTAR PUSTAKA}

Djamarah, Syaiful Bahri Djamarah dan Aswan Zain. 2006. Strategi Belajar Mengajar. Jakarta: PT Rineka Cipta.

Departeman Agama, Direktorat Jendral Kelembagaan Agama Islam. 2005 Pedoman PelaksanaanPembelajaran Tematik. Jakarta.

Apartanto, Iyus dan M. Dahlan Al Bahri. 1994. Kamus Ilmiah Populer. Surabaya PT Arkola.

Purwodarminto, W.J.S. . 1987 Pusat Pembinaan dan Pengembangan Bahasa Departemen Pendidikan dan Kebudayaan, Kamus Umum Bahasa Indonesia. Jakarta: Balai Pustaka.

Sagala, Syaiful. 2006. Konsep dan makna pembelajaran. Bandung: CV Alfabeta.

Sulhan, Najib. 2006. Pembangunan karakter anak manajemen pembelajaran guru menuju sekolah efektif. Surabaya: SIC.

Sanjaya, Wina. 2005. Pembelajaran dalam implementasi kurikulum berbasis kompetensi, Jakarta: Kencana Prenada Media Group.

Hadi, Sutrisno.2001. Metodologi Research. Jilid 1. Yogyakarta: Andi Offset. 
I'anatut Thoifah - Efektivitas Pembelajaran Tematik Pada... 